\title{
Hemşirelik Öğrencilerinin Mesleki Güdülenme Düzeyleri ve Etkileyen Faktörler
}

\section{Nursing Students' Level of Vocational Motivation and Affecting Factors}

\author{
Sevim ÇELIK ${ }^{1}$ \\ Elif ŞAHIN ${ }^{I}$ \\ Figen $D A D A K^{1}$ \\ Sare Gül SIDAL ${ }^{1}$ \\ Fatma $A K Y \ddot{U} Z^{1}$ \\ ${ }^{1}$ Bülent Ecevit \\ Üniversitesi, Zonguldak \\ Să̆llk Yüksekokulu, \\ Hemşirelik Bölümü \\ Yazışma adresi/ \\ Coresspondence \\ Dr. Sevim ÇELIK, Bülent \\ Ecevit Üniversitesi \\ Zonguldak Săglı \\ Yüksekokulu \\ Să̆llk Birimleri Kampusü \\ Abaz Mevkii Kozlu/ \\ Zonguldak \\ sevimakcel@yahoo.com
}

Geliş Tarihi /Recevied 07/05/2014

Kabul Tarihi/Accepted 08/09/2014

HSP 2014; 1(2):43-56
Özet

Amaç: $\mathrm{Bu}$ araştırmanın amacı, öğrenci hemşirelerin mesleki güdülenme düzeylerini ve etkileyen faktörleri belirlemektir.

Yöntem: Bu kesitsel tipte tanımlayıcı araştırmanın örneklemini 622 öğrenci hemşire oluşturmuştur. Veriler anket formu, Güdülenme Kaynakları ve Sorunları Ölçeği kullanılarak toplanmıştır. Verilerin değerlendirilmesinde tanımlayıcı istatistikler, pearson korelasyon analizi, student $\mathrm{t}$ testi ve Mann Whitney $\mathrm{U}$ testi kullanılmıştır. Bulgular: Öğrencilerin içsel güdülenme puan ortalaması $38,98 \pm 8,21$, dişsal güdülenme puan ortalaması 19,52 $\pm 3,65$, olumsuz güdülenme puan ortalaması $23,63 \pm 5,63$ ve Güdülenme Kaynakları ve Sorunları Ölçeği puan ortalaması $82,06 \pm 11,95$ olarak saptanmıştır. $\mathrm{K}$ ız öğrencilerin $(\mathrm{p}=0,00)$, birinci sınıf öğrencilerinin $(\mathrm{p}=0,00)$, ailesinde sağlık çalışanı olmayanların $(\mathrm{p}=0,02)$, insanlara yardım etmeyi sevenlerin $(\mathrm{p}=0,00)$ güdülenme düzeyleri anlamlı şekilde yüksek bulunmuştur. Hemşirelik hakkındaki olumlu düşüncelerin öğrencilerin güdülenme düzeylerinde anlamlı şekilde etkili olduğu belirlenmiştir $(\mathrm{p}=0,00)$. Sonuç: Hemşirelik öğrencilerinin içsel güdülenme düzeyleri dişsal güdülenme düzeylerinden yüksektir. Bu bağlamda, eğitim müfredatında ve eğitim yöntemlerinde öğrencilerin güdülenmelerini arttırıcı değişikliklere yer verilmelidir.

Anahtar kelimeler: Öğrenci hemşire, güdülenme, hemşirelik, hemşirelik eğitimi

\section{Abstract}

Aim: The aim of this study is to determine nusring students' level of vocational motivation and affecting factors. Method: The sample of cross-sectional descriptive study was consisted of 622 nursing students. Data were gathered using questionnaire form and Motivation's Resources and Problems Scale. It was used descriptive statistics, pearson correlation analysis, student t-test and Mann Whitney U test in data analysis.Results: It was determined that mean score of intrinsic motivation of the students was $38,98 \pm 8,21$, mean. The mean score of extrinsic motivation was $19,52 \pm 3,65$ and mean score of negative motivation was $23,63 \pm 5,63$. It was found that mean score of Motivation's Resources and Problems Scale was $82,06 \pm 11,95$. It was found that motivation levels of female students $((\mathrm{p}=0,00)$, first class students $(\mathrm{p}=0,00)$, students who have not health professional in the family $(\mathrm{p}=0,02)$ and students who loves to help people $(p=0,00)$ were significantly higher. It was determined that the students' positive thoughts about nursing were significantly affected on levels of their motivation $(\mathrm{p}=0,00)$. Conclusion: Levels of nursing students' intrinsic motivation were higher than level of extrinsic motivation. In this context, it should be included increasing motivation for training ciriculum and training methods.

Key words: Nursing student, motivation, nursing, nursing education 


\section{Giriş}

Eğitim; bireyin davranışlarında kendi yaşantısı yoluyla ve kasıtlı olarak istendik değişme, meydana getirme sürecidir. Bu süreçte etkili olan kavramlardan biri de güdülenmedir. ${ }^{1}$ Güdülenme insan davranışlarını etkileyen çeşitli faktörler arasında, davranışın yönünü, şiddetini, kararlılığını belirleyen en önemli güç kaynağıdır. Güdü, istekleri, gereksinimleri, ilgileri, dürtüleri içine alan bireylerin çeşitli ihtiyaçlarını karşılamaları için doyum sağlayacak ya da amaca götürecek davranışlarda bulunma sürecidir. Güdülenme insan davranışlarına şekil verme işlevini üstlenen eğitim-öğretim çalışmalarında önemli bir yere sahiptir. $^{2-3}$

Hemşirelik öğrencilerinin etkili öğrenme ve kendini geliştirme yönündeki istekliliklerinin ya da akademik başarıyı etkileyen sorunların önemli bir kısmı güdülenme ile açıklanır. Bunu açıklamak için Deci ve Ryan tarafından geliştirilen teoriden yararlanılır. $\mathrm{Bu}$ teori içsel güdülenme, dişsal güdülenme ve olumsuz güdülenme olmak üzere üç faktörden oluşmaktadır. ${ }^{4-6}$

İçsel güdülenme kişinin kendi içinden, kendi isteği ile başarılı olma arzusudur. Zihinsel aşamada nereye gideceğinizi aklınızda oluşturmak ve kavramak, fiziksel aşamada ise gidilecek noktaya doğru harekete geçmektir. Öğrencinin hemşirelik mesleğine ilgi duyması, mesleği ile ilgili bilgileri öğrenmeyi istemesi, kendi alanında kariyer yapma olanağının olması, aldığı eğitimin yaşam kalitesini arttıracağına inanması gibi duygu ve düşünceler içsel güdülenmeye örnek olarak verilebilir., ${ }^{4,6}$

Dışsal güdülenme bireyin dışındaki faktörlerden, çalışma çevresinden kaynaklanmaktadır ve genelde motive edilen kişinin başka bir kişi tarafından bir takım araçlar kullanılarak motive edilmesiyle uygulanır. Öğretimin beklentileri karşılaması, eğitim alınan grubun istekli olması, öğrencinin bilgi ve becerilerini doğru kullanması sırasında takdir edilmesi öğrenciler için dışsal güdülenme kaynakları arasında yer almaktadır., ${ }^{4,6}$

Olumsuz güdülenme bireylerin hareketleri ile sonuçların meydana getirdikleri arasında bağlantı kuramadıkları durumlarda güdülenmenin olmamasıdır. Güdülenmeyen bireyler ne içsel olarak, ne de dişsal olarak güdülenmiş olabilirler. Bireyler güdülenmediklerinde kendi davranışlarının, kontrollerinin dışında bir şeyin sonucu olduğuna inanırlar. ${ }^{7}$ Öğrencinin kendini yetersiz görmesi, öğrenmek için çaba göstermemesi, baskı altında olmanın ya da hata yapma korkusunun öğrenmeyi olumsuz etkilemesi olumsuz güdülenmede etkili olan değişkenler olarak belirtilmektedir. ${ }^{4,6} \mathrm{Bu}$ üç güdülenmeden en önemlisi bireyin içinden gelen güdülerdir. Daha iyi güdülenme ve performans sağlamak için dişsal güdülenmenin içsel güdülenmeye dönüştürülmesi gerekmektedir. Öğrenciler dışsal güdülenme ile öğrenme eylemini gerçekleştirirken isteksizlik, ilgisizlik ve direnç gösterebilirken, içsel güdülenme; yaratıcı ve yüksek kalitede öğrenmeye yol açtığı ve kişinin bilgisini, inançlarını başarılı davranışlarla bütünleştirdiği için eğitimciler tarafından tercih edilir. ${ }^{3,4,6}$

Eğitimciler hemşirelik eğitimi yaparken insan sağlığı ile ilgili olduğundan bu mesleği seçen öğrencinin fiziksel, zihinsel ve ahlaksal varlığında bir değişikliği, gerçekleştirecek eylemleri gelişmeyi ortaya koyan, mesleğe bakış açısında olumlu ve 
ileriyi gören, günümüz toplumunda modern profesyonel bir kişi olarak işlevlerini yapacak meslek üyelerini yetiştirecek biçimde olmalıdır. ${ }^{8}$

Hemşirelik öğrencileri eğitim süreçleri boyunca, mesleği sevmeme, teorik bilgileri çok kısa sürede işleme, bu yoğun bilgilerin hepsini öğrenmekle sorumlu olma, yoğun zaman baskısı yaşama, klinik uygulamalarda hastanede veya yabancı bir ortamda bulunma, uygulamalarda hata yapma korkusu, klinik uygulamalarda deneyimlerin yeterli olmamas1, klinik ortamın ve ekibin yarattığı stresörler, hasta bireylerle ve hasta yakınlarıyla uğraşma, hastanede çalışanlarla olan iletişim sorunları, öğretim elemanı ve öğrenciler arasında yaşanan sorunlar, ders uygulamalarında ve bakım vermede yetersiz olma gibi çeşitli güçlükler yaşamaktadırlar. Hemşirelik öğrencileri yaşadıkları çatışmaların yanı sıra barınma, ders çalışma olanakları ve kaynak yetersizliği gibi sorunlar da yaşamaktadırlar. ${ }^{1,4,9}$

Hemşirelik eğitimi bu yönleriyle oldukça stres yüklü bir eğitimdir. Böylesine stresli bir eğitim de öğrencileri olumsuz olarak etkilemektedir. Bütün bu nedenler öğrencilerde güdülenmeyi azaltmaktadır. Oysa öğrenme, problem çözme gibi yeteneklerin gelişmesi için öğrencinin güdülenmesi çok önemlidir. ${ }^{1}$ Hemşirelik eğitiminde yaşanan sorunlara çözüm üretmek ve eğitim kalitesini yükseltmek için öğrencilerin öğrenme isteğini arttıracak önlemlerin alınması gerekmektedir. Öğrenmeyi etkileyen önemli unsurlardan biri olarak kabul edilen güdülenme etkeninin nasıl kontrol edilebileceği önemli bir sorun oluşturmaktadır. Bu sorunun çözümü için öncelikle hemşire öğrencilerin güdülenmesini etkileyen ve sorun oluşturan yapıların belirlenmesi gerekmektedir. Güdülenme bireyin öğrenmesinde ve öğrenme ortamının düzenlemesinde önemli bir etkendir. ${ }^{2}$

Hemşirelik eğitiminde kalitenin arttırılması, ileride meslek yaşamında mesleğini severek ve isteyerek yapacak hemşireler yetiştirilmesi ve yaşanan sorunlara çözüm üretilmesi için hemşirelik eğitimi alan öğrencilerin güdü kaynaklarının ve sorunlarının belirlenmesi önem taşımaktadır. ${ }^{10} \mathrm{Bu}$ doğrultuda araştırma, öğrenci hemşirelerin mesleki güdülenme düzeyleri ve etkileyen faktörleri incelemek amacıyla yapılmıştır. $\mathrm{Bu}$ genel amaç çerçevesinde aşağıdaki sorulara yanıt aranmıştır:

- Öğrencilerin öğrenim gördükleri okul ile mesleki güdülenme düzeyleri arasında fark var midir?

- Öğrencilerin bireysel özellikleri ile mesleki güdülenme düzeyleri arasında fark var midir?

- Öğrencilerin ailevi özellikleri ile mesleki güdülenme düzeyleri arasında fark var midir?

- Öğrencilerin hemşirelik hakkındaki görüşleri ile mesleki güdülenme düzeyleri arasında fark var mıdır?

\section{Gereç ve Yöntem}

Araştırmanın Tipi: Hemşirelik bölümünde eğitimlerini sürdüren öğrencilerin mesleki güdülenme kaynaklarını ve sorunlarını belirlemek amacıyla yapılan kesitsel tipte tanımlayıcı bir araştırmadır.

Araştırmanın Yapıldığı Yer: Araştırma 2013-2014 eğitim öğretim yılı bahar yarıyılında 
Bülent Ecevit Üniversitesi Sağlık Yüksekokulu Hemşirelik Bölümü ve Zonguldak’a en yakın uzaklıkta bulunan Hacettepe Üniversitesi Hemşirelik Fakültesi'nde gerçekleştirilmiştir.

Araştırmanın Evreni ve Örneklemi: Araştırmanın evrenini; Zonguldak Bülent Ecevit Üniversitesi Sağlık Yüksekokulu Hemşirelik Bölümü birinci, ikinci, üçüncü ve dördüncü sınıf toplam 440 hemşirelik öğrencisi ve Hacettepe Üniversitesi Hemşirelik Fakültesi birinci, ikinci, üçüncü sınıf toplam 360 hemşirelik öğrencisi olmak üzere toplamda 800 hemşirelik öğrencisi oluşturmuştur. Araştırmada örneklem belirleme yöntemine başvurulmamış tüm evrene ulaşılması hedeflenmiştir. Araştırma; araştırmaya katılmaya gönüllü, Türkçe okuryazarlığı olan, görsel, işitsel, duyusal, algısal herhangi bir hastalığ1 olmayan ve araştırmanın yapıldığ 1 tarihlerde izinli veya devamsız olmayan 622 öğrenci ile gerçekleştirilmiştir. Fakültede okuyan 4. sınıf öğrencilerine güz döneminde mezun oldukları için ulaşılamamış, bu nedenle kapsam dışı bırakılmışlardır. Araştırmaya katılım oran $1 \% 77,75$ 'dir.

Araştırmanın Değişkenleri: Veri toplama formunda mesleksel güdülenme ölçeğinin yanı sıra, öğrencilerin güdülenme kaynakları ve sorunlarını etkileyebileceği düşünülen eğitimin sürdüğü okul, sınıf, cinsiyet ve hemşireliği tercih nedeni gibi bağımsız değişkenler de sorgulanmıştır. Araştırmanın bağımlı değişkenleri öğrencilerin içsel güdülenme, dışsal güdülenme ve olumsuz güdülenme durumlarıdır.

Veri Toplama Araçları: Araştırmada veri toplama aracı olarak anket formu ve Güdülenme Kaynakları ve Sorunları Ölçeği kullanılmıştır.

Anket formu: $\mathrm{Bu}$ form literatür bilgisi doğrultusunda araştırmacılar tarafindan oluşturulmuştur. ${ }^{1,2}$ Öğrencilerin sosyo-demografik özellikleri ve mesleğe ilişkin tutumlarını değerlendirmek amacıyla hazırlanan 11 soru bulunmaktadır.

Güdülenme Kaynakları ve Sorunları Ölçeği: 24 sorudan oluşan bu ölçek 2006 yılında Acat ve Köşgeroğlu ${ }^{2}$ tarafından geliştirilerek geçerlilik ve güvenilirlilik çalışması yapılmıştır. Bu ölçek “' İçsel Güdülenme”, ,'Dışsal Güdülenme', ve 'Olumsuz Güdülenme', olmak üzere toplam 3 alt boyuttan oluşmaktadır. Ölçekte ifadeler hakkındaki görüşler 5'li likert ile puanlanmıştır. Ölçek toplam 24 maddeden oluşmakta olup bunların 11 maddesi içsel güdülenmeyi (1, 2, 3, 4, 6, 7, 8, 9, 10, 23, 24 no' lu maddeler), 5 maddesi dışsal güdülenmeyi $(13,14,15,17,20$ no' lu maddeler) ve 8 maddesi olumsuz güdülenmeyi $(5,11,12,16,18,19,21,22$ no' lu maddeler) belirlemeye yöneliktir. İçsel ve Dışsal güdülenme alt ölçeklerini oluşturan maddelerde "hiç katılmıyorum:1, katılmıyorum: 2, kararsızım: 3, katıliyorum: 4, kesinlikle katıliyorum: 5 " puan verilir. Olumsuz güdülenme alt ölçeğini oluşturan maddelerde " 'hiç katılmıyorum: 5, katılmıyorum: 4, kararsızım: 3, katılıyorum: 2, kesinlikle katılıyorum: 1" puan verilir. Ölçekte içsel güdülenme "en az : 11 - en çok : 55", dişsal güdülenme "en az : 5 - en çok : 25 " ve olumsuz güdülenme "en az : 8 - en çok : 40" olmak üzere toplamda "en az : 24 - en çok:120” puan alınabilir. Her bir alt ölçeğin puanı, ilgili alt ölçek maddelerinin aritmetik puan ortalaması alınarak belirlenmekte, toplamı kişinin mesleksel öğrenme güdülenme düzeyinin puanını oluşturmaktadır. Elde edilen puan ne kadar yüksekse güdülenme düzeyi 
de o kadar fazla olmaktadır bu nedenle toplam ölçek skoru hesaplanırken olumsuz güdülenme alt ölçeğini oluşturan maddelerin puanları ters çevrilmiştir. Ölçeğin iç tutarlılık katsayısı (Cronbach alfa katsayısı ) 0.82 olarak bildirilmiştir. Bu güncel çalışmada ölçeğin Cronbach alfa katsayısı 0.80 olarak bulunmuştur.

Veri Toplama Süreci: Öğrenciler araştırmanın amaçları, formların eksiksiz ve dikkatli bir şekilde doldurulması gerektiği, elde edilen verilerin sadece bilimsel amaçlı kullanılacağı doğrultusunda bilgilendirilmiştir. Araştırmaya katılmaya gönüllü olanlar araştırma veri formunu gözlem altında doldurmuşlardır. Anketler; Şubat- Nisan 2014 tarihleri arasında öğrencilere uygulanmıştır. Anketleri öğrenciler 15-20 dk'da tamamladıktan sonra araştırmacılar tarafından hemen geri toplanmıştır.

Verilerin Değerlendirilmesi: Anket sonucunda elde edilen veriler SPSS for Windows 15.0 programı kullanılarak analiz edilmiştir. Verilerin analizi için; frekans, yüzde, pearson korelasyon analizi, student $\mathrm{t}$ testi ve Mann Whitney $\mathrm{U}$ testi kullanılmıştır. Anlamlılık $\mathrm{p}<0,05$ düzeyinde değerlendirilmiştir.

Etik Yönü: Araştırmaya başlamadan önce her iki kurumun etik kurulu'ndan onay alındıktan sonra, araştırmanın yapılacağı her iki kurumdan ve Güdülenme Kaynakları ve Sorunları Ölçeği’nin geçerliği ve güvenirliğini yapan Acat ve Köşgeroğlu' 'ndan da yazılı izin alınmıştır. Öğrenciler araştırmanın amaçları doğrultusunda bilgilendirilerek sözlü onayları alınmıştır.

\section{Bulgular}

$\mathrm{Bu}$ bölümde araştırmadan elde edilen verilerin istatistiksel değerlendirmesi sonucu ulaşılan bulgular; hemşire adaylarının demografik özelliklerine, öğrencilerin hemşirelik mesleğini tercih nedenlerine, hemşirelik mesleği hakkındaki düşünceleri, öğrencilerin öğrenim gördükleri okuldan beklentilerine, öğrencilerin hemşirelik mesleği hakkındaki düşüncelerine ilişkin bulgular tablo şeklinde sunulmuştur.

Araştırmaya katılan öğrencilerin \%79,7'sinin kadın, \%20,3’ünün erkek olduğu, \% 67,5'inin yüksekokul, \%32,5'inin fakülte öğrencisi olduğu, \%35,0'inin birinci sinıf ve \%24,8'inin ikinci sınıfta öğrenim gördüğü, \%74,9'unun ailesinde sağlık çalışanı olmadığı belirlenmiştir (Tablo 1).

Öğrencilerin çoğunluğunun hemşirelik mesleğini kolay iş bulabileceğini düşündüğü (\%67,5), insanlara yardım etmeyi istedikleri $(\% 30,1)$ ve giriş puanı bu bölüme yeterli geldiği $(\% 20,4)$ için tercih ettiği görülmüştür (Tablo 2). 
Tablo 1. Öğrencilerin Demografik Özellikleri (N=622)

\begin{tabular}{lll}
\hline Özellik & Ortalama & Standart Sapma \\
\hline Yas & 21,13 & 1,86 \\
\hline Cinsivet & Sayı & Yüzde \\
\hline Kadın & 496 & 79,7 \\
Erkek & 126 & 20,3 \\
\hline Okuduğu Okul & & \\
\hline Yüksekokul & 420 & 67,5 \\
Fakülte & 202 & 32,5 \\
\hline Sınıf & & \\
Bïr & 218 & 35,0 \\
İki & 154 & 24,8 \\
Üç & 148 & 23,8 \\
Dört & 102 & 16,4 \\
\hline Ailede Sağlık Calısanı Varlı̆̆ & & \\
\hline Var & 156 & 25,1 \\
Yok & 466 & 74,9 \\
\hline
\end{tabular}

Tablo 2. Öğrencilerin Hemşirelik Mesleğini Tercih Nedenleri (N=622)

\begin{tabular}{lcc} 
Özellik & Sayı* $^{*}$ & Yüzde** $^{* *}$ \\
\hline Kolay iş bulabilme olanağı & 420 & 67,5 \\
İnsanlara yardım etmeyi isteme & 187 & 30,1 \\
Giriş puanı & 127 & 20,4 \\
Maaşın iyi olması & 121 & 19,5 \\
Ailesinin istemesi & 120 & 19,3 \\
Mesleği seviyor olma & 3 & 0,5 \\
Mecbur kalınması & 1 & 0,2 \\
Sağlık meslek lisesi mezunu olma & 4 & 0,6 \\
Kendi tercihi & 1 & 0,2 \\
Öğretmen yönlendirmesi & 1 & 0,2 \\
Masa başı işi olmaması & 1 & 0,2 \\
\hline
\end{tabular}

* Birden fazla yanıt verilmiştir. ** Yüzdeler N(622) sayısına göre alınmıştır.

Öğrenci hemşirelerin meslek hakkındaki meslek hakkındaki düşüncelerini gösteren dağılım incelendiğinde; \%55,3'ünün hemşireliğin önemli bir meslek olduğunu düşündüğü, \%75,1'inin mezuniyet sonrası hemşire olarak çalışmak istedikleri, \%34,1'inin toplumun hemşireliğe bakışının olumsuz olduğunu ve \%33,8'inin de olumlu olduğunu düşündükleri saptanmıştır (Tablo 3). 
Tablo 3. Öğrencilerin Hemşirelik Mesleği Hakkındaki Düşünceleri (N=622)

\begin{tabular}{|c|c|c|}
\hline Özellik & Sayı* & Yüzde ${ }^{* *}$ \\
\hline Önemli bir meslek olduğunu düşünüyor & 344 & 55,3 \\
\hline Çalışma saatleri çok yorucu & 206 & 33,1 \\
\hline \multicolumn{3}{|l|}{ Toplumun hemşireliğe bakış açısı } \\
\hline Olumlu buluyor & 210 & 33,8 \\
\hline Olumsuz buluyor & 212 & 34,1 \\
\hline Kararsiz & 200 & 32,2 \\
\hline Tam ona göre bir meslek & 104 & 16,7 \\
\hline Kişiliğiyle örtüşmüyor & 101 & 16,2 \\
\hline Statü açısından kendisine uygun bulmuyor & 82 & 13,2 \\
\hline \multicolumn{3}{|l|}{ Mezuniyet sonrası hemşirelik yapma durumu } \\
\hline İstiyor & 467 & 75,1 \\
\hline İstemiyor & 155 & 24,9 \\
\hline
\end{tabular}

* Birden fazla yanıt verilmiştir. ** Yüzdeler N(622) sayısına göre alınmıştır.

Araştırmaya katılan hemşire adaylarının öğrenim gördükleri okuldan beklentilerini gösteren dağılım incelendiğinde; \%65,8'inin öğretim elemanları öğrenciye destek olmalı görüşünü destekledikleri, \%5,5'inin de okuldan beklentisi olmadığı görüşünde oldukları görülmüştür (Tablo 4).

Tablo 4. Öğrencilerin Öğrenim Gördükleri Okuldan Beklentileri (N=622)

\begin{tabular}{lcc}
\hline Özellik & Sayı $^{*}$ & Ÿ̈zde** $^{* *}$ \\
\hline Öğretim elemanları ögrenciye destek olmalı & 409 & 65,8 \\
Mesleki bilgi ve becerileri ağırlıklı olmalı & 325 & 52,3 \\
Olanaklar arttırılmalı & 254 & 40,8 \\
Beklentisi yok & 34 & 5,5 \\
\hline
\end{tabular}

* Birden fazla yanıt verilmiştir. ** Yüzdeler N(622) sayısına göre alınmıştır.

Hemşirelik öğrencilerinin Güdülenme Kaynakları ve Sorunları Ölçeği’nin içsel güdülenme alt ölçeğinden ortalama 38,98 $\pm 8,21$, dişsal güdülenme alt ölçeğinden $19,52 \pm 3,65$, olumsuz güdülenme alt ölçeğinden $23,63 \pm 5,63$ puan ve toplamda $82,06 \pm 11,95$ puan aldıkları belirlenmiştir (Tablo 5).

Tablo 5. Hemşirelik Öğrencilerinin Güdülenme Kaynakları ve Sorunları Ölçeğinden Aldıkları Puan Ortalamaları $(\mathrm{N}=622)$

\begin{tabular}{llc}
\hline & Ortalama \pm SS & Puan aralığı \\
\hline İçsel Güdülenme & $38,98 \pm 8,21$ & $11-55$ \\
Dişsal Güdülenme & $19,52 \pm 3,65$ & $5-25$ \\
Olumsuz Güdülenme & $23,63 \pm 5,63$ & $8-40$ \\
Toplam Ölçek Puanı & $82,06 \pm 11,95$ & $24-120$ \\
\hline
\end{tabular}

Hemşirelik öğrencilerinin yaş ortalamaları ile mesleki güdülenme düzeyleri arasında negatif yönde zayıf bir ilişki $(\mathrm{p}=0,00)$ olduğu görülmektedir. Aynı tabloda şekilde kızların $(\mathrm{p}=0,00)$, hemşirelik fakültesinde $(\mathrm{p}=0,24)$ ve birinci sınıfta okuyan öğrencilerin $(\mathrm{p}=0,00)$, ailesinde sağlık çalışanı olmayanların $(\mathrm{p}=0,02)$ mesleki güdülenme düzeylerinin daha yüksek olduğu görülmektedir (Tablo 6). 
Tablo 6. Hemşirelik Öğrencilerinin Mesleki Güdülenme Düzeylerinin Demografik Özelliklere Göre Karşılaştırılması (N=622)

\begin{tabular}{|c|c|c|c|}
\hline Özellik & Ortalama \pm SS & $\mathbf{r}$ & $\mathbf{p}$ \\
\hline \multirow[t]{2}{*}{$\underline{\text { Yas }}(21,13 \pm 1,86)$} & $82,06 \pm 11,95$ & $-0,10$ & $0,01 *$ \\
\hline & Ortalama \pm SS & $\mathbf{t}$ & p \\
\hline \multicolumn{4}{|l|}{ Cinsivet } \\
\hline $\mathrm{K} 1 \mathrm{Z}$ & $82,87 \pm 12,19$ & 3,71 & $0,00 *$ \\
\hline Erkek & $78,86 \pm 10,41$ & & \\
\hline \multicolumn{4}{|l|}{ Okuduğu Okul } \\
\hline Yüksekokul & $81,31 \pm 11,58$ & $-2,26$ & 0,24 \\
\hline Fakülte & $83,61 \pm 12,59$ & & \\
\hline \multicolumn{4}{|l|}{ Sinif } \\
\hline Bir & $83,95 \pm 11,63$ & & \\
\hline İki & $79,55 \pm 11,61$ & 6,73 & $0,00 *$ \\
\hline Üç & $83,65 \pm 12,40$ & & \\
\hline Dört & $79,47 \pm 11,50$ & & \\
\hline \multicolumn{4}{|c|}{ Ailede Sağlık Calısanı Varlı̆̆ı } \\
\hline Var & $80,24 \pm 11,48$ & $-2,20$ & $\mathbf{0 , 0 2 *}$ \\
\hline Yok & $82,66 \pm 12,06$ & & \\
\hline
\end{tabular}

Tablo 7 incelendiğinde, öğrencilerin hemşirelik mesleğini tercih nedenleri arasında insanlara yardım etmeyi sevme nedeninin istatistiksel anlamlı şekilde mesleki güdülenme düzeylerinde etkili olduğu belirlenmiştir $(p=0,00)$. Diğer tercih nedenlerinin öğrencilerin mesleki güdülenme puan ortalamalarında istatistiksel anlamlı farklılık oluşturmadığ1 saptanmıştır. Aynı tablo, mecbur kaldığı ve insanlara yardım etmeyi sevdiği için tercih edenlerin en yüksek, masa başı iş olmaması ve sağlık meslek lisesi mezunu olması nedeniyle tercih edenlerin ise en düşük mesleki güdülenme düzeyi puan ortalamasına sahip olduklarını göstermiştir (Tablo 7).

Tablo 7. Hemşirelik Öğrencilerinin Mesleki Güdülenme Düzeylerinin Hemşireliği Tercih Nedenine Göre Karşılaştırılması ( $\mathrm{N}=622)$

\begin{tabular}{llccc}
\hline Özellik & $\begin{array}{c}\text { Evet } \\
\text { Ortalama } \pm \text { SS }\end{array}$ & $\begin{array}{c}\text { Hayır } \\
\text { Ortalama } \pm \text { SS }\end{array}$ & t & p \\
\hline Kolay iş bulabilme olanağ1 & $81,94 \pm 11,12$ & $82,30 \pm 13,54$ & $-0,32$ & 0,74 \\
Giriş puanı & $81,11 \pm 11,66$ & $82,30 \pm 12,03$ & $-1,00$ & 0,31 \\
İnsanlara yardım etmeyi isteme & $88,80 \pm 11,22$ & $79,16 \pm 11,07$ & 9,91 & $\mathbf{0 , 0 0 *}$ \\
Maaşın iyi olması & $82,94 \pm 12,20$ & $81,84 \pm 11,90$ & 0,90 & 0,36 \\
Ailesinin istemesi & $80,98 \pm 12,65$ & $82,31 \pm 11,78$ & $-1,09$ & 0,27 \\
& & & $\mathbf{Z}$ & $\mathbf{p}$ \\
Mesleği seviyor olma & $86,33 \pm 5,68$ & $82,04 \pm 11,97$ & $-0,81$ & 0,41 \\
Mecbur kalınması & 94,00 & $82,04 \pm 11,95$ & $-1,16$ & 0,24 \\
Sağlık meslek lisesi mezunu olma & $75,25 \pm 7,13$ & $82,10 \pm 11,97$ & $-1,36$ & 0,17 \\
Kendi tercihi & 81,00 & $82,06 \pm 11,96$ & $-0,00$ & 0,99 \\
Ö̆ğretmen yönlendirmesi & 80,00 & $82,06 \pm 11,96$ & $-0,12$ & 0,89 \\
Masa baş1 işi olmaması & 66,00 & $82,08 \pm 11,95$ & $-1,43$ & 0,15 \\
\hline
\end{tabular}


Tablo 8, öğrenci hemşirelerin çalışma saatlerinin çok yorucu olduğunu düşünmeleri $(\mathrm{p}=0,50)$ dışında, diğer hemşirelik mesleği hakkındaki görüşlerinin mesleki güdülenme puan ortalamalarında etkili olduğunu $(\mathrm{p}=0,00)$ göstermiştir. Buna göre, önemli ve tam ona göre bir meslek olduğunu düşünen, kişiliğiyle örtüşmediğini ve statü açısından kendisine uygun bulmadığını düşünmeyen, toplumun bakış açısının olumlu olduğunu düşünen ve bu konuda kararsızlık yaşayan öğrencilerin, mezuniyet sonrası bu mesleği yapmayı isteyenlerin mesleki güdülenme puan ortalamalarının daha yüksek olduğu görülmüştür.

Hemşire adaylarının öğrenim gördükleri okuldan beklentilerine göre mesleki güdülenme düzeyleri puanlarının sonuçları incelendiğinde (Tablo 9); mesleki bilgi ve becerileri ağırlıklı olmalı diyen grubun ortalama mesleki güdülenme puanı en yüksek iken; öğrenim gördükleri okuldan beklentisi olmayan grubun ortalama puanının en düşük olduğu saptanmıştır. Ayrıca, "mesleki bilgi ve becerilerin ağırlıklı olmasını isteyenler $(p=0,00)$ ile okulda olanakların arttırılmasını bekleyenlerin $(\mathrm{p}=0,03)$ hemşire adaylarının güdülenme düzeyleri puan ortalamalarında istatistiksel anlamlı farklılık oluştuğu bulunmuştur.

Tablo 8. Hemşirelik Öğrencilerinin Mesleki Güdülenme Düzeylerinin Hemşirelik Mesleği Hakkındaki Düşüncelerine Göre Karşılaştırılması (N=622)

\begin{tabular}{|c|c|c|c|}
\hline Özellik & Ortalama \pm SS & $\mathbf{t}$ & p \\
\hline \multicolumn{2}{|l|}{ Önemli bir meslek olduğunu düşünüyor } & \multirow{3}{*}{8,82} & \multirow{3}{*}{$\mathbf{0 , 0 0 *}$} \\
\hline Evet & $85,64 \pm 11,22$ & & \\
\hline Hayır & $77,62 \pm 11,35$ & & \\
\hline \multicolumn{4}{|l|}{ Kişiliğiyle örtüşmüyor } \\
\hline Evet & $73,69 \pm 10,69$ & \multirow[t]{2}{*}{$-8,07$} & \multirow[t]{2}{*}{$\mathbf{0 , 0 0 *}$} \\
\hline Hayır & $83,68 \pm 11,51$ & & \\
\hline \multicolumn{4}{|l|}{ Tam ona göre bir meslek } \\
\hline Evet & $88,14 \pm 13,41$ & \multirow[t]{2}{*}{5,19} & \multirow[t]{2}{*}{$0,00 *$} \\
\hline Hayır & $80,83 \pm 11,26$ & & \\
\hline \multicolumn{4}{|l|}{ Çalışma saatleri çok yorucu } \\
\hline Evet & $82,51 \pm 11,47$ & \multirow[t]{2}{*}{0,67} & \multirow[t]{2}{*}{0,50} \\
\hline Hayır & $81,83 \pm 12,19$ & & \\
\hline \multicolumn{4}{|l|}{ Statü açısından kendisine uygun bulmuyor } \\
\hline Evet & $77,78 \pm 13,10$ & \multirow[t]{2}{*}{$-3,51$} & \multirow[t]{2}{*}{$\mathbf{0 , 0 0 *}$} \\
\hline Hayır & $82,71 \pm 11,65$ & & \\
\hline \multicolumn{4}{|l|}{ Toplumun hemşireliğe bakış açısı } \\
\hline Olumlu buluyor & $84,23 \pm 11,35$ & \multirow[t]{3}{*}{21,14} & \multirow[t]{3}{*}{$\mathbf{0 , 0 0 *}$} \\
\hline Olumsuz buluyor & $77,85 \pm 12,14$ & & \\
\hline Kararsiz & $84,23 \pm 11,22$ & & \\
\hline $\begin{array}{l}\text { Mezuniyet sonrası } \\
\text { durumu }\end{array}$ & & 11,27 & $0,00 *$ \\
\hline İstiyor & $84,90 \pm 11,08$ & & \\
\hline İstemiyor & $73,50 \pm 10,31$ & & \\
\hline
\end{tabular}


Tablo 9. Hemşirelik Öğrencilerinin Mesleki Güdülenme Düzeylerinin Öğrenim Gördükleri Okuldan Beklentilerine Göre Karşılaştırılması (N=622)

\begin{tabular}{lccc}
\hline Özellik & Ortalama \pm SS & t & p \\
\hline Öğretim elemanları öğrenciye destek olmalı & & & \\
$\quad$ Evet & $82,56 \pm 12,01$ & & \\
Hayır & $81,08 \pm 11,82$ & 1,47 & 0,14 \\
\hline Mesleki bilgi ve becerileri ağırlıklı olmalı & & & \\
$\quad$ Evet & $83,99 \pm 11,52$ & & \\
Hayır & $79,94 \pm 12,08$ & 4,27 & $\mathbf{0 , 0 0 *}$ \\
\hline Olanaklar arttırılmalı & & & \\
$\quad$ Evet & $83,33 \pm 12,94$ & & \\
Hayır & $81,18 \pm 11,16$ & 2,14 & $\mathbf{0 , 0 3 *}$ \\
\hline Beklentisi yok & & & \\
$\quad$ Evet & $79,41 \pm 13,89$ & & \\
Hayır & $82,21 \pm 11,83$ & $-1,32$ & 0,18 \\
\hline
\end{tabular}

$* \mathbf{p}<0,05$

\section{Tartışma}

Araştırma kapsamına alınan hemşire adaylarının içsel ve dışsal güdülenme düzeylerinin yüksek, olumsuz güdülenmenin düşük olduğu görülmüştür. Gençay ve Gençay’ın yaptığ1 çalışmada, öğrencilerin dışsal motivasyon ortalamalarının daha yüksek olduğu saptanmıştır. ${ }^{11}$ Özlü ve arkadaşları ${ }^{12}$ da çalışmalarında öğrenci hemşirelerde olumsuz güdülenme puan ortalamalarının diğer güdülenme türlerine göre daha yüksek olduğunu saptamışlardır. $\mathrm{Bu}$ farklılığın araştırmaların farklı öğrenci gruplarında ve kurumlarda yapılmış olmasından kaynaklandı̆̆ı düşünülmektedir. İçsel güdülenme kaynaklarının öğrenmede daha güçlü ve daha sürekli motivasyon sağladığı belirtilmektedir. ${ }^{13}$ Ayrıca öğrencilerin içsel güdülenme düzeylerinin yüksek olmasının, hem eğitim sürecinde hem de çalışma hayatı sürecinde mesleğin kalitesinin artmasına katkı sağlayacağ düşünülmektedir. $\mathrm{Bu}$ çalışmada hemşirelik öğrencilerinin toplam güdülenme düzeyleri ortalamanın biraz üzerinde bulunmuştur. Araştırmadan elde edilen bulgu önceki literatür bilgisi ile benzerlik göstermektedir. ${ }^{4}$ Önceki çalışmalarda ${ }^{3,14-16}$ da mesleki güdülenmenin, mesleğin kazandıracağı prestij, elde edilecek yüksek ücret, mesleğe ve bilime duyulan ilgi, insanlara yardım etme ve fedakarlık duygularının yüksek olması ile artacağı vurgulanmaktadır. Bir mesleği en iyi şekilde yapmaya aday bu öğrencilerin, güdülenme düzeylerinin daha yüksek olması beklenirken ortalamanın biraz üzerinde bulunmasının, ülkemiz koşullarında hemşirelik eğitiminde yaşanan sorunlardan kaynaklandığı düşünülmektedir.

$\mathrm{Bu}$ araştırmada, hemşire adaylarının mesleksel öğrenme güdülenme düzeyleri ile cinsiyetleri arasında anlamlı bir fark olduğu $(\mathrm{p}=0,00)$ ve hemşirelik bölümünün daha çok k1z öğrenciler tarafından tercih edildiği belirlenmiştir. İflazoğlu ve Tümkaya ${ }^{17}$, yaptığ çalışmanın sonucunda öğrencilerin cinsiyetleri ve güdülenme düzeyinin kız öğrencilerin lehine anlamlı bir farkın olduğunu belirtmiştir. Özellikle toplumumuzda, hemşirelik mesleğinin toplumsal cinsiyet acısından da ele alındığında "kadına özgü" meslek grubu olarak algılandığı bilinmektedir. Bu algı da öğrencilerin tercihlerinde etkili olmaktadır. ${ }^{18}$ 
Araştırmada, hemşirelik öğrencilerinin fakülte veya yüksekokulda öğrenim görmelerinin mesleki güdülenme düzeylerini etkilemediği saptanmıştır. Buna karşılık hemşire adaylarının mesleki güdülenme düzeyleri ile sınıfları arasında anlamlı bir fark bulunmuştur. $\mathrm{Bu}$ farkın dördüncü sınıfların mesleki güdülenme düzeylerinin düşük olmasından kaynaklandığ 1 belirlenmiştir. Son sınıf öğrencilerinin mesleğe atılmaya yönelik yaşadıkları streslerin güdülenme düzeylerinin düşük olmasında etkili olduğu düşünülmektedir. Birinci sınıfta okuyan öğrencilerin güdülenme düzeyi diğer sınıflara göre daha yüksek bulunmuştur $(\mathrm{p}=0,00)$. Bunun en önemli nedeninin öğrencilerin mesleğe yeni adım atmalarıyla ilgili yaşadığı heyecandan kaynaklandığı düşünülmektedir. Civci ve Şener'in yaptığı araştırmada birinci ve dördüncü sınıflar arasında mesleki güdülenme düzeyleri arasında fark bulunmamıştır. ${ }^{1}$

Ailesinde sağlık çalışanı olmayan hemşirelik öğrencilerinin mesleki güdülenme düzeyi daha yüksek bulunmuştur. Ailesinde sağlık çalışanı olan öğrencilerin mesleki avantaj ve dezavantajları hakkında ön bilgiye sahip olmaları nedeniyle güdülenme düzeyleri farklılık göstermektedir.

Araştırma sonuçları incelendiğinde, öğrencilerin hemşirelik mesleğini tercih nedenleri arasında insanlara yardım etmeyi sevme nedeninin mesleki güdülenme düzeylerinde etkili olduğu belirlenmiştir $(\mathrm{p}=0,00)$. Diğer tercih nedenlerinin öğrencilerin mesleki güdülenme düzeylerinde farklılık oluşturmadığı saptanmıştır. Öğrencilerin mecbur kaldığ olmaması ve sağlık meslek lisesi mezunu olması nedeniyle tercih edenlerin ise en düşük mesleki güdülenme düzeyi puan ortalamasına sahip oldukları belirlenmiştir. Nilsson ve Stomberg de $\mathrm{de}^{19}$ öğrenci hemşireler ile yaptığı çalışmada, öğrencilerin insanlara yardım etmeyi ve yararlı olmayı istedikleri için hemşireliği tercih ettiklerini belirtmişlerdir. Eskimez ve arkadaşlarının ${ }^{20}$ yapmış olduğu bir çalışmada, öğrencilerin hemşirelik mesleğini tercih etme nedenlerinin dağılımına bakıldığında, insanları ve onlara yardım etmeyi sevmenin ilk sırada yer aldığı görülmüştür. Bu tercih nedenini ardından sağlık alanına ilgi duymak ve üniversite giriş puanının bu okul için yeterli olması gibi nedenler izlemektedir. Özpancar ve arkadaşları ${ }^{21}$ tarafından hemşirelik öğrencileri ile yapılmış bir diğer çalışmada da öğrencilerin en çok iş bulma güvencesi, idealindeki meslek olduğu için ve yakın çevresinin etkisiyle mesleği seçtiklerini belirtmişlerdir. Bireylerin kendi istek ve yeteneklerine göre seçtikleri alanda çalıştıklarında mesleki güdülenme düzeyleri yüksek, başarılı ve mutlu oldukları, farklı nedenlerle seçtikleri alanda çalıştıklarında ise güdülenme düzeyi düşük, çalışmaya isteksiz, başarısız ve mutsuz oldukları düşünülmektedir.

Öğrencilerin, hemşirelerin çalışma saatlerinin çok yorucu olduğunu düşünmeleri dışında, önemli ve tam ona göre bir meslek olduğunu düşünen, kişiliğiyle örtüşmediğini ve statü açısından kendisine uygun bulmadığını düşünen, toplumun bakış açısının olumlu olduğunu düşünen ve bu konuda kararsızlık yaşayan öğrencilerin, mezuniyet sonrası bu mesleği yapmayı isteyenlerin mesleki güdülenme düzeylerinin yüksek olduğu gözlenmiştir $(\mathrm{p}=0,00)$. Hemşirelik mesleğinin toplum tarafından kabul görmüş bir meslek olmasının bu sonuçta etkili olduğu düşünülmektedir. Bu sonucun da öğrencilerin tercihlerini bilinçli olarak yaptığının bir ifadesi olduğu düşünülmektedir. Acat ve Köşgeroğlu'nun çalışmalarında, hemşirelik eğitiminde, özellikle uygulamalı derslerde yeteri kadar rol 
modeli olacak eğitimciler tarafından desteklenmediklerinden, öğrencilerin hem güven duygularının yetersiz, hem de eğitime karşı isteksiz oldukları görülmüştür. ${ }^{2}$ Beydağ ve $\operatorname{arkadaşlar1}^{22}$, yaptıkları araştırmada öğrencilerin büyük çoğunluğunun mezun olduktan sonra hemşirelik mesleğini yapmak istedikleri sonucuna ulaşmışlardır.

Araştırmada hemşire adaylarının öğrenim gördükleri okuldan beklentilerine göre mesleki güdülenme düzeyleri arasında, mesleki bilgi ve becerileri ağırlıklı olmalı şeklinde yanıt veren grubun mesleki güdülenme düzeyi en yüksek iken $(p=0,00)$; öğrenim gördükleri okuldan beklentisi olmayan grubun mesleki güdülenme düzeyi en düşük olduğu belirlenmiştir (p>0,05). Beklentisi olmayan öğrencilerin hemşirelik mesleğini benimsemedikleri düşünülmektedir. Hemşire adaylarının geneli teorik derslerde ve uygulama alanlarında öğretim elemanlarının kendilerine destek olmasını istemiştir. Bengtssona ve Ohlssonb ${ }^{23}$ tarafindan İsviçre'de, hemşirelik ve sağlık okuluna devam eden 31 öğrenciyle kalitatif olarak, gerçekleştirilen bir çalışmada da, öğrenciler öğretim elemanlarının, motivasyonlarını etkilediğini belirtmişlerdir. Ayrıca, programın özelliğinin, derslerin içeriğinin, öğretim elemanlarının uyguladıkları stratejilerin ve klinik uygulamaların da motivasyonlarını etkilediklerini belirtmişlerdir. Bu nedenle eğitim ve öğretim elemanlarının anlayışlı, öğrencilerle derslerde ve uygulama alanlarında birebir ilgilenen ve mesleki açıdan donanımlı olmaları sağlanmalıdır. Civci ve Şener'in ${ }^{1}$ yaptıkları araştırmada hemşire adaylarının, \%43,8'i öğretim elemanlarının teorik derslerde ve uygulama alanlarında ögrenciye destek olmasını, \%30,7'si mesleki bilgi ve becerilerin hemşirelik eğitiminde ağırlıklı olmasını beklemektedir.

\section{Sonuç ve Öneriler}

Hemşirelik öğrencilerinde güdülenmenin cinsiyete göre farklılık gösterdiği, kız öğrencilerin güdülenme düzeylerinin daha fazla olduğu saptanmıştır. Öğrencilerin mesleğe ilişkin bakış açışının, toplumun hemşireliğe bakış açısının, mesleğin statüsünün, hemşireliği sevme durumlarının, mezuniyet sonrası hemşire olarak çalışmayı düşünme durumlarının mesleki güdülenmelerinde etkili olduğu belirlenmiştir.

$\mathrm{Bu}$ araştırmadan elde edilen bulgular doğrultusunda;

1. Dışsal motivasyon düzeyleri her ne kadar yüksek çıksa da öğrencileri motive edecek etkinlikler planlanmal1,

2. Mesleği seçen erkek öğrencilerin güdülenme düzeyinin arttırılması ve meslek hakkındaki olumsuz yargılarının kaldırılması için rehberlik-danışmanlık hizmetleri sağlanmalı,

3. Hemşirelik öğrencilerinin hemşireliğin sosyal statüsü ve gelecekte toplumda edinecekleri yer konusunda sahip oldukları olumsuz yargıları giderici eğitim çalışmalarına yer verilmeli,

4. Eğitim süreci içinde verilen derslerde teorik bilginin yanında öğrencilerin kendi yeterliliklerinin farkına varmalarını sağlayacak projelere ve uygulama çalışmalarına ağırlık verilerek hemşirelik mesleğini güdeleyici duruma getirilmeli,

5. Öğretim elemanlarının anlayışlı, öğrencilerle derslerde ve uygulama alanlarında birebir ilgilenen ve mesleki açıdan donanımlı olmaları sağlanmalı,

6. Öğrenci hemşirelere mezuniyetten sonraki çalışma alanları tanıtılarak, mesleğe farklı alanlardan bakış acısı kazandırılmalı ve hedeflerini belirlemede yardımcı olunmalıdır. 


\section{Kaynaklar}

1. Civci H, Şener E. Hemşire adaylarının mesleki güdülenme düzeyleri ve etkileyen faktörlerin belirlenmesi. DEUHYO ED 2012; 5(4): 142-149.

2. Acat B, Köşgeroğlu N. Güdülenme kaynakları ve sorunları ölçeği. Anadolu Psikiyatri Dergisi 2006; 7: 204-210.

3. Gayef A, Sarıkaya Ö. Sağlık hizmetleri meslek yüksekokulu öğrencilerinde mesleki güdülenme. Tıp Ĕ̈itimi Dünyası Dergisi 2012; 33: 9-18.

4. Özkan S, Yılmaz E. Hemşirelik öğrencilerinin güdülenme düzeylerinin belirlenmesi. Ege Üniversitesi Hemşirelik Yüksek Okulu Dergisi 2009; 25(3): 55-68.

5. Deci EL, Ryan RM. Self-determination theory and the facilitation of intrinsic motivation, social development, and well-being. American Psychologist 2000; 55: 68-78.

6. Ryan R, Deci EL. Intrinsic and extrinsic motivation: classic definition and new directions. Contemporary Educational Psychology 2000; 25: 54-67.

7. Vallerand RJ, Bissonette R. Intrinsic, extrinsic, and amotivational styles as predictors of behavior: a prospective study. Journal of Personality 1992; 60: 599-620.

8. Şirin A, Öztürk R, Bezci G, Çakar G, Çoban A. Hemşirelik öğrencilerinin meslek seçimi ve mesleği uygulamaya yönelik görüşleri. Dirim Tıp Gazetesi, 2008; 83: 69-75.

9. Karadağ G, Güner İ, Çuhadar D, Uçan Ö. Gaziantep Üniversitesi Sağlık Yüksekokulu hemşirelik öğrencilerinin benlik saygıları. Fırat Sağlık Hizmetleri Dergisi 2008; 3(1):2942.

10. Turgay AS, Karaca B, Çeber E, Aydemir G. Hemşirelik öğrencilerinin mesleği algılayışları. Atatürk Üniversitesi Hemşirelik Yüksekokulu Dergisi 2005;8(1):54-62.

11. Gençay ÖA, Gençay S. Beden eğitimi ve spor yüksekokulu öğrencilerinin öğretmenlik mesleğine ilişkin motivasyon düzeylerinin bazı değişkenler açısından incelenmesi. Selçuk Üniversitesi Sosyal Bilimler Dergisi 2007; 17: 241-253.

12. Özlü ZK, Gümüş K, Güngörmüş K, Avşar G, Özer N. Sağlık bilimleri fakültesinde öğrenim gören öğrencilerin mesleki güdülenme kaynakları ve sorunlarının incelenmesi. Hemşirelikte Ĕgitim ve Araştırma Dergisi 2014; 11(1):47-53.

13. Xiang $P$, Chen $A$, Bruene $A$. Interactive impact of intrinsic motivators and extrinsic rewards on behavior and motivation outcomes. Journal of Teaching in Physical Education 2005; 24: 179-197.

14. Öztürk H. Hemşirelerde motivasyon düzeyleri ve performans düzeyleri. Yayınlanmamış Doktora Tezi, İstanbul: İstanbul Üniversitesi Sağlık Bilimleri Enstitüsü, Hemşirelik Anabilim Dalı, İstanbul, 2002.

15. Crossley ML, Mubarik AA. Comparative investigation of dental and medical student's motivation towards career choice. British Dental Journal 2002; 193: 471-473.

16. Engin E. Psikiyatri kliniğinde çalışan hemşirelerin öfke düzeyleri ile iş motivasyonları arasındaki ilişkinin incelenmesi. Yayınlanmamış Doktora Tezi, Ege Üniversitesi Sağlık Bilimleri Enstitüsü Psikiyatri Hemşireliği Programı, İzmir, 2004.

17. İflazoğlu A, Tümkaya S. Öğretmen adayların güdülenme düzeyleri ile drama dersindeki akademik başarıları arasındaki ilişkinin incelenmesi. Pamukkale Üniversitesi Ĕ̆itim Fakültesi Dergisi 2008; 23 (1): 61-73. 
18. Çiftçi G, Bülbül S. Sağlık bilimleri fakültesini tercih eden öğrencilerin, üniversite ve meslek tercihlerinde etkili olan faktörler. J Kartal TR 2011; 22(3):151-160.

19. Nilsson KEL, Stomberg MW. Nursing students motivation toward their studies- a survey study. BioMed Central Nursing 2008; 7(6):1-7.

20. Eskimez Z, Öztunç G, Alparslan N. Lise son sınıfta okuyan kız öğrencilerin hemşirelik mesleğine ilişkin görüşleri. Hacettepe Üniversitesi Sağllk Bilimleri Fakültesi Hemşirelik Dergisi 2008: 58-67.

21. Özpancar N, Aydın N, Akansel N. Hemşirelik 1. Sınıf öğrencilerinin hemşirelik mesleği ile ilgili görüşlerinin belirlenmesi. C.Ü. Hemşirelik Yüksekokulu Dergisi 2008; 12(3):9-17.

22. Beydağ D, Gündüz A, Özer FG. Sağlık yüksekokulu öğrencilerinin eğitimlerine ve mesleklerine bakış açıları, meslekten beklentileri. Pamukkale Tıp Dergisi 2008; 1(3): 137142.

23. Bengtssona $\mathrm{M}$, Ohlssonb $\mathrm{B}$. The nursing and medical students motivation to attain knowledge. Nurse Education Today 2010; 30(2): 150-156. 